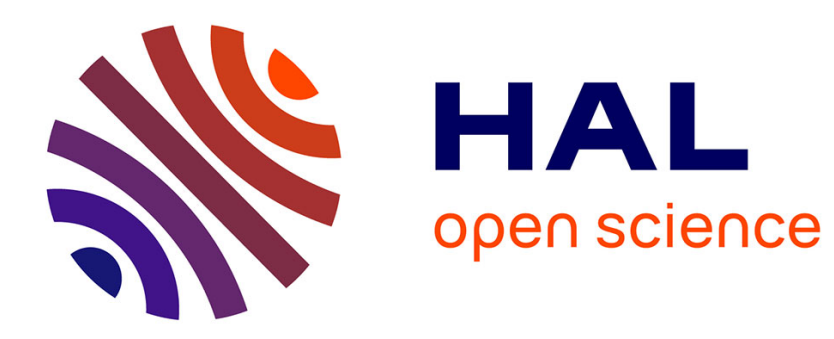

\title{
Microvariation in verbal and nominal agreement: An analysis of two Lombard Alpine dialects
}

\author{
Diego Pescarini
}

\section{To cite this version:}

Diego Pescarini. Microvariation in verbal and nominal agreement: An analysis of two Lombard Alpine dialects. Probus, In press, 10.1515/probus-2021-0003 . hal-03094907v2

\section{HAL Id: hal-03094907 \\ https://hal.science/hal-03094907v2}

Submitted on 8 Sep 2021

HAL is a multi-disciplinary open access archive for the deposit and dissemination of scientific research documents, whether they are published or not. The documents may come from teaching and research institutions in France or abroad, or from public or private research centers.
L'archive ouverte pluridisciplinaire HAL, est destinée au dépôt et à la diffusion de documents scientifiques de niveau recherche, publiés ou non, émanant des établissements d'enseignement et de recherche français ou étrangers, des laboratoires publics ou privés. 


\title{
Microvariation in verbal and nominal agreement: An analysis of two Lombard Alpine dialects
}

\author{
Diego Pescarini \\ CNRS, Université Côte d'Azur, BCL
}

\begin{abstract}
In Bregagliotto and Mesolcinese, two Lombard Alpine dialects, feminine plural agreement/concord is marked by the formative $-n$, a reflex of the 3 rd person plural verbal ending. In Bregagliotto, plural $-n$ triggers mesoclisis of the feminine subject clitic in contexts of inversion, whereas in the noun phrase $-n$ behaves as a second-position element marking plural feminine concord. Mesolcinese exhibits verbal gender agreement as the formative $-n$ occurs on the inflected verb whenever a feminine plural subject or the feminine plural object clitic occurs; in feminine plural DPs, $-n$ is attached to any element except the definite article. I argue that the Bregagliotto system emerged when $-n$ was reanalysed as an adjunct pluraliser, whereas in Mesolcinese $-n$ has been turned into a marker of morphophonological concord/agreement.
\end{abstract}

Keywords: agreement, concord, microvariation, mesoclisis, metathesis, adjunction, labeling, ItaloRomance

\section{Introduction}

This article deals with agreement in two Italo-Romance (groups of) dialects that are spoken in two valleys of southern Switzerland: the Mesolcina and the Bregaglia valley. Although both 
belong to the canton of Grisons, the two valleys are separated by orographic, linguistic, and administrative barriers (Grassi 2008). ${ }^{1}$

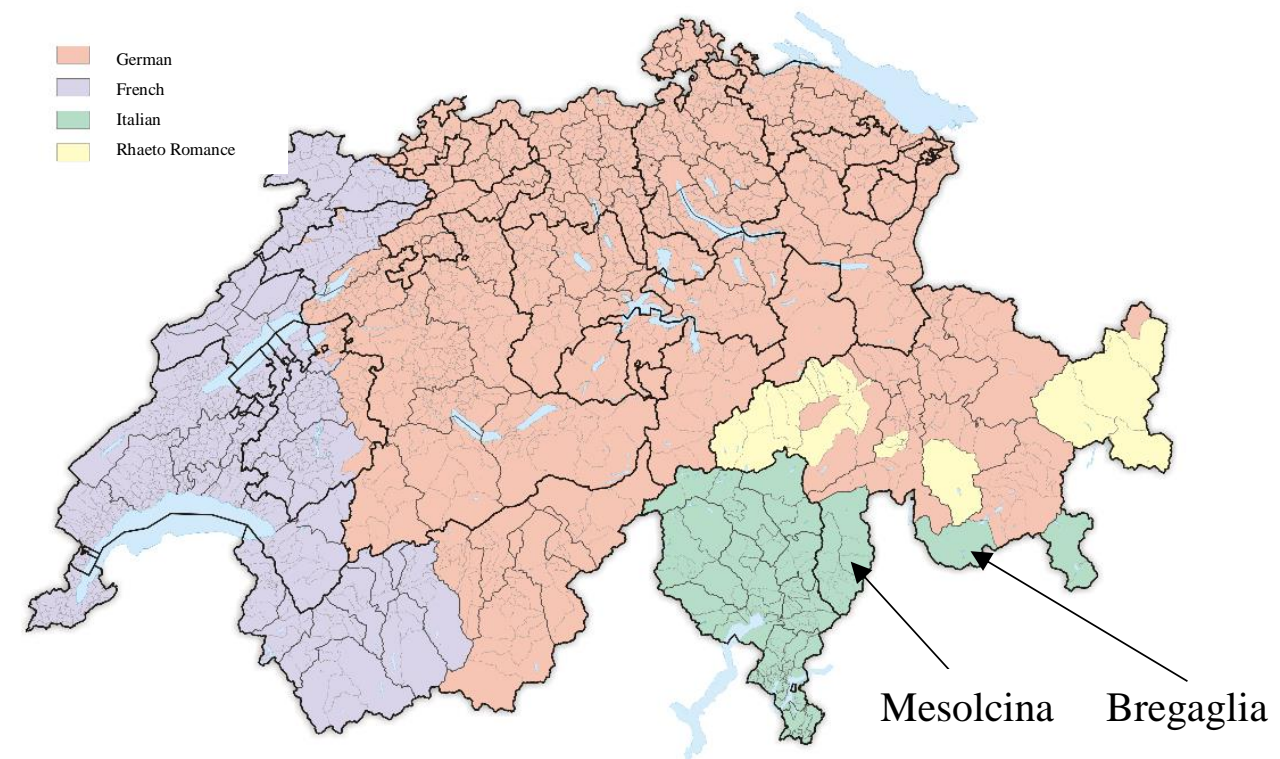

Fig. 1 - Linguistic areas of Switzerland (2017)

(C) Tschubby - CC BY-SA 3.0, https://commons. wikimedia.org/w/index.php?curid=54356841

The main characteristics of Mesolcinese and Bregagliotto are briefly summarised as follows (some of these remarks will be refined in due course):

- In both groups of dialects, feminine plural agreement in the Determiner Phrase (DP) is marked by the ending $-n$ (I will refer to this phenomenon as ' $\mathrm{N}$ marking').

1 For helpful comments on a previous draft of this paper, I wish to thank Michele Loporcaro, Giampaolo Salvi, Roberta D’Alessandro, Adam Ledgeway, Luigi Rizzi, Diana Passino, Cecilia Poletto, Andrea Scala, Rita Manzini, Leonardo Savoia, two anonymous reviewers, and audiences in Zurich and Milan. 
- $\quad \mathrm{N}$ marking is asymmetric and, at first sight, the asymmetry in one variety seems the mirror image of the asymmetry in the other: in Mesolcinese the suffix $-n$ tends to occur on the rightmost elements in the DP, whereas in Bregagliotto - $n$ usually occurs on determiners, see (1)a.

- In both varieties, $-n$ (which is a reflex of the 3rd person plural verbal ending) occurs on finite verbs. In Mesolcinese - $n$ occurs if and only if either the subject, see (1)b, or the object, see (1)c, are feminine plural. In Bregagliotto, conversely, $-n$ occurs with all $3^{\text {rd }}$ person plural subjects regardless of their gender, see (1)b, and it never marks object agreement.

(1) a. nominal agreement:

\begin{tabular}{|l|l|l|l|l|}
\cline { 2 - 5 } \multicolumn{1}{c|}{} & \multicolumn{1}{c|}{ M.SG } & \multicolumn{1}{c|}{ M.PL } & \multicolumn{1}{c|}{ F.SG } & \multicolumn{1}{c|}{ F.PL } \\
\hline Mesolcinese & l so 'dzi:u & i so 'dzi: & la so 'dzi:a & la son 'dzien \\
\hline Bregagliotto & el se 'dzi:o & i se dzi: & le se 'dzi:a & len se 'dzi:a \\
& 'his/her uncle' & 'his/her uncles' & 'his/her aunt' & 'his/her aunts' \\
\hline
\end{tabular}

b. verb-subject agreement:

\begin{tabular}{|l|l|l|l|l|}
\cline { 2 - 5 } \multicolumn{1}{c|}{} & \multicolumn{1}{c|}{ M.SG } & \multicolumn{1}{c|}{ M.PL } & \multicolumn{1}{c|}{ F.SG } & \multicolumn{1}{c|}{ F.PL } \\
\hline Mesolcinese & l dis & i dis & la dis & la 'dizen \\
\hline Bregagliotto & el di: & i 'dizen & la di: $\int$ & la 'dizen \\
& 'he says' & 'they.M say' & 'she says' & 'they.F say' \\
\hline
\end{tabular}

c. verb-object agreement in Mesolcinese:

la 'tfamion (Mes.)

her= I.call-FPL

'I call them.F' 
The data introduced in (1) raise three main research questions:

i) How to account for Number agreement in the (Romance) DP? Scholars such as Ritter 1991, 1992; Bernstein 1991; Picallo 1991 argue that Number is encoded in a dedicated functional head (e.g. NumP), whereas Dobrovie-Sorin 2012, Cyrino \& Espinal 2015, 2020 entertain the hypothesis that the Plural obtains when a modifier is adjoined to the functional spine of DPs. Related issues are the position of the element encoding Number, see (ii), and the nature of the agree relationship between $\mathrm{D}, \mathrm{N}$, and other nominal modifiers (see Cyrino \& Espinal 2015 on Inverse Agree, Mathieu 2009 on Cyclic Agree).

ii) How to account for asymmetric agreement/concord? Various explanations have been discussed in the recent literature to account for variation in asymmetric/partial/“lazy" agreement systems (for an overview, see Stark \& Pomino 2009). Variation in nominal agreement may depend on where Number is probed/merged/interpreted: D (Delfitto \& Schrotten 1991, Bouchard 2002), Num (Rasom 2008), D or $n$ (Dobrovie-Sorin 2012), D, $n$ or - to a lesser extent - A (Cyrino \& Espinal 2020). Additionally, scholars such as Bonet, Lloret \& Mascarò 2015, Cyrino \& Espinal 2020 entertain the hypothesis that asymmetric agree may results from postsyntactic concord, which triggers the externalisation of Number/Gender features within a given Spell-Out domain (Cyrino \& Espinal 2020: 187; see also Manzini \& Savoia 2019, Manzini et al. 2021).

iii) How to account for the similarities between clausal agreement and nominal concord? The idea that the DP and the clause have isomorphic structures has been proposed in Abney 1987, Ritter 1991, 1992; Bernstein 1991 argued that inflectional positions such as Number Phrase (NumP) are sandwiched between NP and DP, yielding a layered structure $(\mathrm{D}>\mathrm{Num} / \mathrm{Gen}>\mathrm{N})$ analogous to the clausal one $(\mathrm{C}>\mathrm{Agr} / \mathrm{T}>\mathrm{V})$. The parallelism between DP and CP is revived by Manzini \& Savoia's 2019 analysis of 
Mesolcinese, which revolves around the hypothesis that the externalization of agreement features is sensitive to syntactic phases (Chomsky 2001).

The above research questions will be addressed in the light of data from Mesolcinese and Bregagliotto. These Lombard Alpine dialects have been extensively debated in the dialectological literature, most of which focused on the synchronic distribution of $-n$ and its possible etymology, see Ascoli 1875: 269-270, 273-274; Schuchardt 1880:153; Meyer-Lübke 1890(II): §32-33; Salvioni 1902: 139; Keller 1932; Sganzini 1933; Jaberg 1951; Tuttle 1982, Loporcaro 2006; Pescarini 2020. This article aims to provide a closer comparison between Mesolcinese and Bregagliotto in the light of data from the aforementioned literature, from syntactic atlases (in particular the AIS), and from my own fieldwork notes. I intend to show that Bregagliotto provides crucial evidence to reach a better understanding of Mesolcinese, which exhibits a more innovative and peculiar system.

From a theoretical standpoint, I argue that the agreement phenomena we find in present-day Mesolcinese and Bregagliotto originated from the syntactic reanalysis of a morphophonological irregularity that is still visible in Bregagliotto. In Bregagliotto the plural verbal ending $-n$ undergoes metathesis when it is followed by the feminine plural enclitic $l a$, yielding the order Root $>l a>-n$ that is unparalleled in the other Italo-, Gallo-, and Rhaeto-Romance dialects. I argue that this morpho-phonological irregularity triggered a sequence of three cascading changes:

i) First, $-n$ was reanalysed as an adjunct PLURALISER (Wiltschko 2008; Dobrovie-Sorin 2012; Cyrino \& Espinal 2020), which is not incorporated by the verb.

ii) The PLURALISER is merged with Person probes such as T and D (Longobardi 2008). Person probes were thus the pivots triggering the emergence of $\mathrm{N}$-marking in the DP.

iii) Differences between the two varieties result from the status of $n$ : in Bregagliotto $n$ still lexicalises the adjunct PLURALISER, whereas in Mesolcinese it externalises number agreement via morphophonological concord (Cyrino \& Espinal 2020). 
The structure of the article is as follows: $§ 2$ focuses on metathesis and mesoclisis; $\S 3$ and $\S 4$ explore a syntactic analysis of the Bregagliotto $\mathrm{T}$ and D systems, respectively; $§ 5$ argues that in Mesolcinese the formative $n$ is a marker of morphophonological agreement/concord; $\S 6$ elaborates on the other properties that distinguish Mesolcinese from Bregagliotto: gender and object agreement on finite verbs; §7 concludes.

\section{The genesis of $\mathbf{N}$ marking}

The table in (2) compares the distribution of $-n$ in the clause (DPs will be examined in $\S 5$ ): in Mesolcinese, $-n$ is suffixed to the verb whenever a feminine plural subject or object clitic occurs.

Conversely, in Bregagliotto $-n$ is the regular ending of all $3^{\text {rd }}$ person plural verbs, regardless of the gender of subjects and objects. 
(2) Distribution of $n$ in the clause:

\begin{tabular}{|l|l|l|}
\cline { 2 - 3 } \multicolumn{1}{l|}{} & Mesolcinese & Bregagliotto \\
\hline a. SCl V & $\begin{array}{l}\text { (F) la 'dizen } \\
\text { (M) i dis } \\
\text { 'they say' }\end{array}$ & $\begin{array}{l}\text { (F) la 'fyman } \\
\text { (M) i 'fyman } \\
\text { 'they smoke' }\end{array}$ \\
\hline b. V SCl & $* 2$ & (F) 'drom-la-n? \\
(M) 'dromen-i?
\end{tabular}

Bregagliotto is more conservative than Mesolcinese under three main respects:

i) In Bregagliotto, verb-subject (clitic) inversion is fully productive;

ii) in Bregagliotto, finite verbs never agree in gender with object clitics (as in the vast majority of Italo-Romance dialects);

iii) Bregagliotto exhibits no gender verbal agreement as verbal morphology is regular ($n$ is the 3rd person plural ending of the verb, regardless of the gender of the subject).

The only irregularity displayed by Bregagliotto is that the subject clitic la 'her/they.F' precedes the formative $-n$ when it is enclitic, yielding a pattern of mesoclisis, cf. (2)b. As shown in (3) $b,(4) b,(5) b)$, the $-n$ ending of $3^{\text {rd }}$ person plural verbs always follows the feminine subject clitic $l a$, while it precedes the masculine clitic $-i$ (as is customary in all the Romance languages that show subject clitic inversion, which always yields the order Root $>$ Inflection $>$ inverted subject clitic):

2 Mesolcinese has lost inversion. 
(3) a. i/la 'dromen (Bre.; Manzini \& Savoia 2005.I:371)

3NOM.M.PL/F= sleep-PL

'They.M/F sleep.'

b. 'dromen-i? / / drom-la-n?

sleep-PL $=3$ NOM.M.PL $\quad$ sleep $=3$ NOM.F $=P L$

'Do they.M/F sleep?'

(4) a. l’ an (Bre.; Salvioni 1902: 135)

3NOM.F=have-PL

'They.F have.'

b. à-la-n?

have $=3 \mathrm{NOM} . \mathrm{F}=\mathrm{PL}$

'Do they.M/F have?'

(5) a. l' en

3NOM.F=be-PL

'They.F are.'

b. e-la-n? (Bre.; Salvioni 1902: 135)

$\mathrm{be}=3 \mathrm{NOM} \cdot \mathrm{F}=\mathrm{PL}$

'Are they.M/F?'

Since mesoclisis is the only anomaly in the distribution of $-n$ and it correlates with the presence of feminine plural subjects, it seems plausible that the pattern in (3)b, (4)b, (5)b played a role in the emergence of $\mathrm{N}$ marking. Before exploring this possibility in greater detail (in $\S 3$ ), some remarks on the nature and origin of mesoclisis are in order. 
First of all, mesoclisis of subject clitics is unparalleled and, from a syntactic standpoint, it is completely unexpected: it is a widely held view that enclisis results from movement of the inflected verb to the left periphery (say, to Rizzi’s 1997 Fin), crossing the position harbouring the subject clitic:

(6) $[$ Fin $\mathrm{V}+\mathrm{T} \quad[\mathrm{SCl} \quad[\mathrm{T}(\mathrm{V}+\mathrm{T})$

Since mesoclisis should be impossible under (6), to account for Bregagliotto we must invoke a mechanism that "overrides" (6) when the subject is feminine. The most probable explanation is that mesoclisis was initially triggered at PF by metathesis, a phonological change preventing sequences of sonorants. As shown by numerous examples (e.g. dormir > dromir 'to sleep' in (3)), Lombard (Alpine) dialects tend to avoid clusters of sonorants by reversing the order of segments or syllables. Since the feminine plural enclitic la begins with a sonorant, enclisis yielded a marked cluster of consonants $\left({ }^{*} n l\right)$ that was avoided by means of metathesis, see (7)a. In the masculine, conversely, metathesis did not take place as the sequence formed by the plural ending $-n$ and the masculine plural clitic $i$ is phonologically licit. Consequently, the masculine clitic of Bregagliotto has kept occurring after the agreement ending, see (7)b, as subject enclitics normally do.

(7) Syntax PF

a. $[\mathrm{V}-n[\mathrm{la} \rightarrow$ */-nla/ $>$ /-lan/

b. $[\mathrm{V}-n[i \quad \rightarrow \quad /-n i /$

Although mesoclisis of subject clitics is virtually unattested, similar patterns are found with object clitics in Mexican Spanish varieties (Harris \& Halle 2005): 
a. Venda-n-lo! (Mexican Spanish)

sell-PL=it

b. Venda-lo-n!

sell=it-PL

'Sell it!'

The pattern in (8) has been analysed from both morpho-phonological and syntactic standpoints (see Halle \& Harris 2005 vs Kayne 2010). Evidence for a morphological analysis of (8) comes from instances of reduplication, e.g. venda-n-lo-n and free alternations between (8)a and (8)b (for extensive discussion, see Arregi \& Nevins 2018). However, neither Bregagliotto nor Mesolcinese show instances of reduplication of the Chicano type; moreover, in Bregagliotto mesoclisis is not optional and, most importantly, mesoclisis correlates with extensive patterns of $\mathrm{N}$-marking in the nominal domain and, in Mesolcinese, with verbal gender agreement. These phenomena cannot be accounted for under a morphophonological analysis of the kind proposed by Halle \& Harris 2005 . Hence, although it is likely that mesoclisis originated from metathesis, a syntactic analysis of the successive chronological stages seems definitely on the right track.

In the next section, I will therefore argue that metathesis triggered reanalysis (i.e. syntactic rebracketing) of $-n$ as an adjunct PLURALISER. This in turn triggered a series of further changes that made Bregagliotto and Mesolcinese diverge from the other Lombard dialects and from each other. The hypothesis that a marginal irregularity reverberated throughout the agreement systems of Bregagliotto and Mesolcinese is consistent with the tenets of Longobardi's 2001 Inertial Theory of syntactic change, the gist of which is summarised in the following quote:

"syntactic change should not arise, unless it can be shown to be caused-that is, to be a well-motivated consequence of other types of change (phonological changes and semantic 
changes, including the appearance/disappearance of whole lexical items) or, recursively, of other syntactic changes.” (Longobardi 2001: 278)

According to this view, which is endorsed by the present work, syntactic change cannot result from the invariable principles of Narrow Syntax, which are by definition inert to change. Innovations - and, consequently, variation - is first triggered by reanalysis of interface effects, such as metathesis, which end up modifying the featural endowment of functional elements (where syntactic variation is encoded, according to the so-called Borer-Chomsky Conjecture).

In this respect, it is worth noting that in Lombard Alpine dialects inversion (and, consequently, mesoclisis) was originally much more pervasive than nowadays. In present-day dialects, inversion is found in interrogative clauses, but for centuries northern Italian dialects displayed traces of verb-second syntax of the kind that is still productive in the nearby Rhaeto-Romance varieties spoken in the Grisons (see Fig. 1). This amounts to saying that, in previous diachronic stages, metathesis was more frequent than nowadays and, given its higher incidence, it could have prompted the kind of syntactic reanalysis reconstructed here.

\section{A syntactic analysis of the Bregagliotto T system}

In this section, I entertain the hypothesis that Bregagliotto speakers rebracketed sentences including feminine plural clitics in order to accommodate metathesis. As a consequence, the $-n$ co-occurring with the feminine $l a$ was reanalysed as an adjunct PLURALISER (Wiltschko 2008).

In origin, the ending $-n$ spelled out T's person and number features that are valued via agree(ment) with the subject. As shown in (9)b, $-n$ is merged in $\mathrm{T}$ when $\mathrm{T}$ probes a plural 
subjects such as $i$ 'they.M' (let us assume, for the sake of simplicity, that subject clitics are first merged in $v$ ). The formative $-n$ forms a complex head with the verb and, when the latter moves to $\mathrm{C}$, as in (9)e, $-n$ moves along with the verbal root above the subject clitic $i$, as in the other Romance languages and dialects exhibiting inversion.

(9) a.

$$
[v \text { i drom }] \quad \operatorname{sleep}(\mathrm{x})
$$

b.

$[\mathrm{T}-\mathbf{n}[v$ i drom $]]$

c.

$$
\text { [т droma-n [ } v \text { i droma }] \text { V-to-T }
$$

d. [т i [т droma-n [ $v$ i droma] ] Subj. movement

e. [c droma-n [т і [т droma-n $[v$ i droma $]]]$ T-to-C (inversion)

Sentences featuring feminine plural subjects had - in origin - the same syntactic derivation, until metathesis reversed the order of $-n$ and the feminine enclitic $l a$ at PF, yielding a misalignment between syntax and morphology, in (10)f:

(10) a.

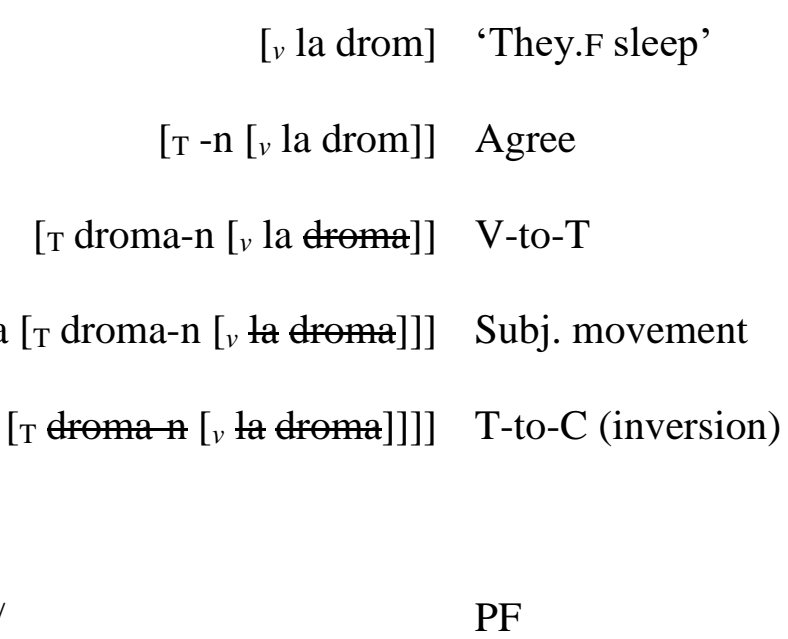

f. /droma la $-\mathrm{n} /$

$\mathrm{PF}$

Across generations, this irregularity triggered rebracketing: as shown in (11)b-c, $n$ does no longer lexicalise T, but it is adjoined to T. From now on I adopt the symbol ${ }^{\wedge}$ (taken from Hornstein \& Nunes 2008) to distinguish the inflectional marker $n$, lexicalising T, from the 
freestanding PLURALISER ${ }^{\wedge} n$ that is adjoined to T. The latter does not belong to the constituent that is subject to movement (Hornstein \& Nunes 2008: 68), possibly because adjuncts are merged "on a separate plane" (Chomsky 2004: 118; see also Chomsky 2020: 47), and is not pied-piped/incorporated by $\mathrm{V} / \mathrm{T} .^{3}$

(11) a.

$$
\text { [v la drom] } \operatorname{sleep}(\mathrm{x})
$$

c.

[т $\mathrm{T}^{\wedge} \mathbf{n}[v$ la drom $\left.\left.]\right]\right]$ The PLURALISER is merged with $\mathrm{T}$

d. [т droma^n ${ }^{\wedge}$ v la droma $\left.\left.]\right]\right] \quad$ V-to-T

e. [т la [т droma^n [v la droma]]]] Subj. movement

f. [с droma [т la [т droma^n $\left[{ }^{\wedge}\right.$ ta droma $\left.\left.\left.]\right]\right]\right] \quad$ T-to-C (inversion), ${ }^{\wedge} n$ is stranded /droma la $\mathrm{n} /$

The PLURALISER ${ }^{\wedge} n$ modifies the vP (along the lines discussed in Bianchi 2008:§3) that in Bregagliotto does not contain Number information as the subject clitic la pronominalizes either singular or plural entities, e.g. la droma 'she/they sleep(s)'. Hence, the PLURALISER $n$ can be merged when the subject is feminine, but it cannot co-occur with the masculine plural $i$ 'they' that carries its own number feature. By the same token, ${ }^{\wedge} n$ cannot be merged to $\mathrm{T}$ if the subject is $1^{\text {st }} / 2^{\text {nd }}$ person since "apparent number on $1^{\text {st }}$ and $2^{\text {nd }}$ person does not instantiate the category Number” (Wiltschko 2008:§2.4.3), a widely held view since Benveniste 1966; Lyons 1968. In case of masculine subjects and $1^{\text {st }} / 2^{\text {nd }}$ person subjects, plural marking is therefore inflectional

3 There are alternative ways to account for the excorporation of $-n$. Calabrese and Pescarini 2014 explored a Distributed Morphology analysis in which metathesis triggers fission of feature bundles. In a previous version of this work I argued for an alternative analysis based on D'Alessandro's 2016, 2017 analysis of central ItaloRomance dialects that display agreement phenomena analogous to those of Bregagliotto and Mesolcinese - i.e. verbal gender agreement and omnivorous agreement (Nevins 2011). D'Alessandro argues that dialects showing gender and/or omnivorous agreement exhibit a complex probe formed by $\mathrm{T}$ and an extra probe $\pi$. However, the analysis proposed in the present work, where I assume that $-n$ becomes an adjunct, seems to me more elegant. 
in nature, i.e. the verbal ending spells out T's agreement features, whereas, with feminine subjects, plural marking is modificational (Wiltschko 2008).

\section{A syntactic analysis of the Bregagliotto D system}

Wiltschko 2008: §2 argues that in several languages number marking is not inflectional, but modificational: the plural obtains by adjoining a PLURALISER to the functional spine of the DP. Dobrovie-Sorin 2012 and Cyrino \& Espinal 2020 propose a similar analysis for Romance. In particular, Cyrino \& Espinal argue that the PLURALISER is a syntactic adjunct to D; witness languages in which plural marking is morphosyntactically encoded on the determiner, e.g. Br. Port. os livros / os livro / *o livros 'the books',

In this section, I argue that the hypothesis of an adjoined PLURALISER accounts for the syntax of $n$ in Bregagliotto, which is exemplified in (12):

(12) Bregagliotto

\begin{tabular}{|l|l|}
\hline a. Art + N & $\begin{array}{l}\text { len ge'nafe } \\
\text { 'the jaws' }\end{array}$ \\
\hline b. Dem + N & $\begin{array}{l}\text { 'kwelan du ga'li:na } \\
\text { 'these two hens' }\end{array}$ \\
\hline c. Q + N & 'tantem 'vo'lte \\
'many times' \\
\hline d. Adj + N & povran gnocca \\
'poor girls'
\end{tabular}




\begin{tabular}{|l|l|}
\hline & 'the big shoulders' \\
\hline f. N (+ Adj) & $\begin{array}{l}\text { Erban verda! } \\
\text { 'green herbs' }\end{array}$ \\
\hline
\end{tabular}

With respect to the data in (12), two main questions need elaboration: i) why ${ }^{\wedge} n$ behaves as a second position element in the DP; ii) how ${ }^{\wedge} n$ became a marker of nominal concord.

The hypothesis that number is encoded by a PLURALISER accounts for the second-position syntax of $\wedge^{\wedge} n$ : since the PLURALISER is merged in $\mathrm{D}, \wedge n$ is correctly predicted to follow all kinds of determiners:

(13) [D 'kwela^n [du [ga'li:na]]]

'these two hens'

The marker ${ }^{\wedge} n$ never occurs in indefinite DPs that are introduced by numerals because, as Wiltschko 2008 points out, adjunct pluralisers are incompatible with DPs that are intrinsically plural:

(14) a. ne 'don:e (Breg.; AISr)

'A woman.'

b. $d \mho(* \wedge \mathbf{n})$ 'don: $\bullet$

two woman $/{ }^{*}$ women

'Two women.'

Adjectives and nouns that precede ${ }^{\wedge} n$ in (12)d-f are not real counterexamples to the hypothesis that ${ }^{\wedge} n$ is merged in $\mathrm{D}$. In fact, head movement to $\mathrm{D}$ is a rather common phenomenon in determiner-less DPs (Longobardi 1994). In this respect, it is worth noting that many instances 
of $\operatorname{Adj}^{\wedge} n$ or $\mathrm{N}^{\wedge} n$ sequences, which nowadays are quite marginal, are found in vocatives, which Espinal 2013 argues to be derived by moving Ns or As to a dedicated position (Voc) above D. Hence, adjectives and nouns precede $-n$ in (12)d-f because they can move to D (or to an even higher position such as Voc) in determiner-less DPs:

$$
\begin{aligned}
& \text { (15) }\left[\mathrm { D } \mathrm { N } \left[{ }^{\wedge} n \quad\right.\right. \text { (N-to-D movement; Longobardi 1994) } \\
& {\left[\operatorname { V o c } \mathrm { N } \left[\mathrm { D } ( \mathrm { N } ) \left[{ }^{\wedge} n \quad\right.\right.\right. \text { (vocatives; Espinal 2013) }}
\end{aligned}
$$

As for the emergence of $\mathrm{N}$-marking in the DP, my explanation relies on the isomorphism between clausal/T and nominal/D domains, which has been widely debated in the generative literature since Abney 1987. T and D play a similar role in the two domains, by anchoring the clause/phrase to the context via deictic features such as Tense, Definiteness, and Person. In my opinion, Person is the pivotal feature that allowed the transfer of agreement morphology (namely, of $\wedge^{\wedge} n$ ) from the verbal to the nominal domain, as shown in (16). Given the constrained distribution of $\wedge_{n}$ in (12) one can eventually hypothesise that the PLURALISER $n$ is subcategorised for person (I will resume this discussion in $\S \S 5-6$ ).

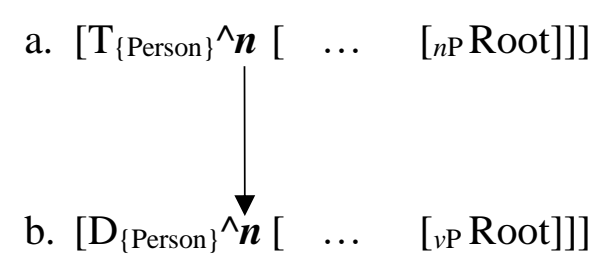

The idea that $\mathrm{D}$, like $\mathrm{T}$, probes Person is supported by evidence of N-to-D movement of pronouns: unlike nouns, personal pronouns bearing Person features move above prenominal modifiers such as numerals in (17) and adjectives in (18) (for further evidence, see Longobardi 
(17) a. [D noi [due [N nøi]]] (It.)

b. [D loro [due [N ๒re]]]

c. [D *amici [due [N amici]]]

'the two of us/the two of them/two friends'
(18) a. [D noi [ricchi]] (It.)
b. [D we [rich]]

To conclude, in this section I argued that the person/number ending $-n$ has been reanalysed as a PLURALISER ${ }^{\wedge} n$ that is adjoined to T (first) and then to both person probes: $\mathrm{T}$ and $\mathrm{D}$. The hypothesis accounts for the extension of ${ }^{\wedge} n$ to the DP, once we assume that i) D probes Person (Longobardi 2008) and ii) in many Romance languages, plural DPs are obtained by merging a PLURALISER in D (Dobrovie Sorin 2012; Cyrino \& Espinal 2020). Since ${ }^{\wedge} n$ is merged with D, it always occurs after the leftmost element of the DP; this accounts for the second-position syntax of the Bregagliotto $n$.

\section{Mesolcinese (vs Bregagliotto): on morphophonological agreement}

Mesolcinese differs from Bregagliotto in two related respects:

\footnotetext{
4 The displacement of personal pronouns in D takes place to value D's Person feature in the same way in which subject move to spec T.
} 
i) Multiple agreement: While in Bregagliotto ${ }^{\wedge} n$ always follows Person probes (and, consequently, occurs once in the clause and once in the DP), in Mesolcinese the formative $n$ occurs on all inflected elements in the clause and in the DP (demonstratives, nouns, quantifiers, past participles, etc.), except the clitic/article la. The distribution in the DP is shown in table (19), which compares N-marking in Bregagliotto and Mesolcinese:

(19) N domain

\begin{tabular}{|l|l|l|}
\cline { 2 - 3 } \multicolumn{1}{l|}{} & Mesolcinese & Bregagliotto \\
\hline a. Art + N & $\begin{array}{l}\text { la ga' nasan } \\
\text { 'the jaws' }\end{array}$ & $\begin{array}{l}\text { len ge'nafe } \\
\text { 'the jaws' }\end{array}$ \\
\hline b. Dem + N & $\begin{array}{l}\text { kelan mat-an } \\
\text { 'these girls' }\end{array}$ & 'kwelan du ga'li:na \\
& 'these two hens' \\
\hline d. Adj + N & 'many cows' & 'tantem 'vo'lte \\
& - & 'many times' \\
\hline e. Art + N + Adj & la 'Spalen 'largen & povran gnocca \\
& 'the big shoulders' & 'poor girls' \\
\hline f. $\mathrm{N}(+\mathrm{Adj})$ & - & 'thn 'Jpal'e 'la'rge big shoulders' \\
\hline & & 'green herbs' \\
\hline
\end{tabular}

i) Participial-like agreement of finite verbs: Mesolcinese finite verbs exhibit two properties that, in other (Italo)Romance varieties, characterise participle agreement, i.e. object-clitic agreement and gender agreement: 
a. inflected verbs end in $n$ when they co-occur with a $3^{\text {rd }}$ person feminine plural object clitic, as in (20); in this case, $n$ occurs regardless of the verb's person specification.

b. verbs at the $3^{\text {rd }}$ person plural exhibit $n$ if the subject is feminine, otherwise they have no ending, see (21);

(20) la 'tfami-ən (Mes.)

them.F $=$ call.1SG-FPL

'I call them.F'

(21)

\begin{tabular}{|l|l|l|l|}
\hline \multicolumn{1}{|c|}{ M.SG } & \multicolumn{1}{|c|}{ M.PL } & \multicolumn{1}{c|}{ F.SG } & \multicolumn{1}{c|}{ F.PL } \\
\hline el dis & i dis & la dis & la 'dizen \\
he= says & they.M= say & she= says & they.F= say-FPL \\
\hline
\end{tabular}

Following Cyrino \& Espinal 2020, I contend that the above differences between Mesolcinese and Bregagliotto result from the morphological mapping of number. Cyrino \& Espinal 2020 argue for a principled distinction between pluralisation (in Syntax) and plural marking (in Morphology): the former is conceived of as syntactic modification (i.e. merger of a PLURALISER), while the latter consists of "morphophonological agreement (or concord) among the constituents within the same Spell-out domain” (Cyrino \& Espinal 2020: 187).

Morphophonological agreement/concord results in the insertion at PF of redundant inflectional exponence, as exemplified in the following examples from Italian (from now on, I will use the symbol + to signal morphophonological exponence): 
(22)

a. $1+\mathbf{a}$ nostr+a car+a amic $+\mathbf{a}$ è $\operatorname{stat+a}$ lasciat+a. (It.)

the-FSG our-FSG dear-FSG friend-FSG is been-FSG left-FSG

'Our nice friend has been left.'

b. $1+\mathbf{e}$ nostr+e car $+\mathbf{e}$ amich $+\mathbf{e}$ sono stat+e lasciat+e.

the-FPL our-FPL dear-FPL friend-FPL are been-FPL left-FPL

'Our nice friends have been left.'

Unlike Italian, various Romance languages/dialects exhibit patterns of morphophonological agreement that are partial/asymmetric/lazy, see Stark \& Pomino 2009 for an overview. Partial marking is usually sensitive to syntactic constituency; Cyrino \& Espinal 2020: 189 propose the following constraint:

(23) Plural-marking-on-D constraint

If $\mathrm{X}$ (that is, a pluralized D) c-commands $\mathrm{Y}$ (that is, $\mathrm{N}$ or $\mathrm{A}$ ), which in its turn c-commands $\mathrm{Z}$ (N or A), plural marking may be overt on $\mathrm{X}$ alone, on $\mathrm{X}-\mathrm{Y}$, on $\mathrm{X}-\mathrm{Y}-\mathrm{Z}$, but not on $\mathrm{X}-\mathrm{Z}$.

The above constraint, however, accounts neither for Bregagliotto nor for Mesolcinese. In the former, $n$ behaves as a second position element, in the latter $n$ occurs on any inflected element except definite articles.

Alternatively, Manzini \& Savoia's 2019; Manzini et al.'s 2020 argue for a more powerful constraint that affects plural marking in the noun phrase and in the clause in parallel fashion. For instance, in the Friulian dialect in (24), the definite article and the object clitic never exhibit the sigmatic plural marker that regularly occurs with other elements such as adjectives, nouns, past participles. 
(24) a. $1-\mathbf{i}\left(*^{*} \mathbf{s}\right)$ bun-is femin-is (Montereale Valcellina, Frl.)

the-PL good-FPL woman-FPL

'the good women'

b. $1-\mathbf{i}\left(*^{*}\right) \quad$ ai $\quad$ klamad-is

3.ACC-PL I.have called-FPL

'I have called them.F'

In Manzini \& Savoia's account, the parallelism between DP and participle agreement is captured by a single parameter that is sensitive to the inner articulation of phases (Chomsky 2001): plural marking is either uniform within the phase or within one of the phase components, the head ${ }^{5}$, the edge, or the complement. The parameter is category-neutral and, in principle, the same parametric choice may determine the distribution of agreement markers in phases (DP, $\mathrm{CP}$, and vP), which - in Manzini \& Savoia's analysis - are headed by determiners, subject clitics, and object clitics, respectively.

Mesolcinese provides strong support for Manzini \& Savoia's 2019 parametric model as $n$ occurs on all nominal element except the definite article $l a$, which can therefore introduce either singular or plural feminine DPs:

a. la to so'rele

(SG; Mes.)

the your sister

'Your sister.'

5 To explain why demonstratives exhibit $-n$ morphology, see (i), one may argue that they are merged in SpecDP and/or they are first merged in the complement of the phrase. On these two options, see Guardiano 2010.

(i) kelan mat-an (Mes.) 'quelle ragazze' 
b. la $(*+n)$ to+n so'rele+n (PL)

the your-FPL sister-FPL

'Your sisters.'

Analogously in the clause $-n$ never occurs on object and subject proclitics, which are homophonous with the definite article.

$(26)$

a. la 'vaka 1'

e mõn'dzuda

(SG; Mes.)

the cow 3.NOM.F $=$ is milked

'The cow is milked.'

$\begin{array}{lllll}\text { b. la } & \text { 'vake+n } & 1(*+a n) & \text { e: }+\mathbf{n} \text { mõn'dzude+n } & \text { (PL) }\end{array}$

the cow-FPL 3.NOM.F $=$ is.FPL milked-FPL

'The cows are milked.'

Mesolcinese thus supports the hypothesis of a category-neutral theory of agreement marking, in which a single parameter affect both nominal and verbal domains, as shown in the following table/diagram (from Manzini \& Savoia 2019): 
(27) Mesolcinese

HEAD \| COMPLEMENT (Manzini \& Savoia 2019, with modifications)

$\begin{array}{llllll}\mathrm{F} & -\mathrm{a} & \| & -\mathrm{y} & -\mathrm{y} & -\mathrm{y} \\ \mathrm{M} & -\mathrm{i} & \| & (-\mathrm{i}) & (-\mathrm{i}) & (-\mathrm{i})\end{array}$

b CP phase: $\mathrm{SCl} \| \quad \mathrm{T}$

$\begin{array}{rlll}\mathrm{F} & -\mathrm{a} & \| & -\mathrm{y} \\ \mathrm{M} & -\mathrm{i} & \| & - \\ \text { c. vP phase: } & \mathrm{OCl} & \| & v \\ \mathrm{~F} & -\mathrm{a} & \| & -\mathrm{y} \\ \mathrm{M} & -\mathrm{i} & \| & (-\mathrm{i})\end{array}$

To conclude, both Bregagliotto and Mesolcinese exhibit systems of partial N-marking that are isomorphic in the clause and in the DP. However, while in Bregagliotto $n$ lexicalises the otherwise abstract PLURALISER (see $\S \S 3-4)$, in Mesolcinese number is externalised via morphophonological concord within a Spell-Out domain. In the latter, $n$ has the same distribution as other inflectional markers such as F.SG - $a$ and is constrained by a parameter along the line of (27). The difference between the two dialects is shown in the following trees (recall that the symbols ${ }^{\wedge},+$ signals syntactic adjunction and insertion at $\mathrm{PF}$, respectively): 
(28) a. Bregagliotto

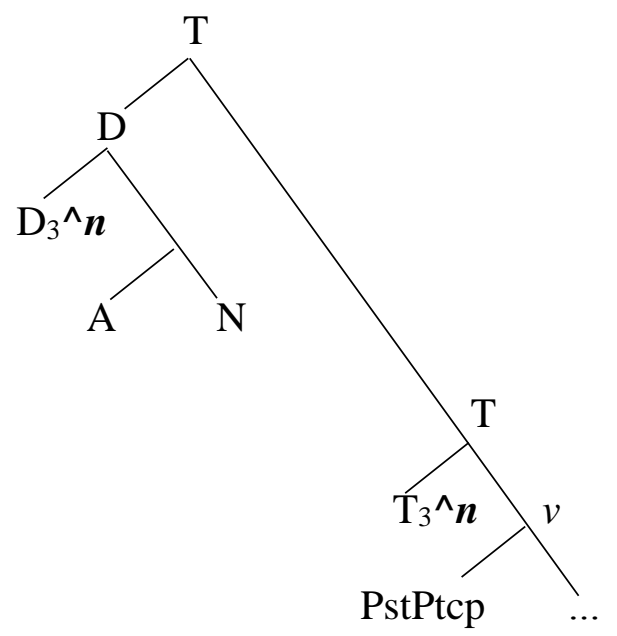

b. Mesolcinese

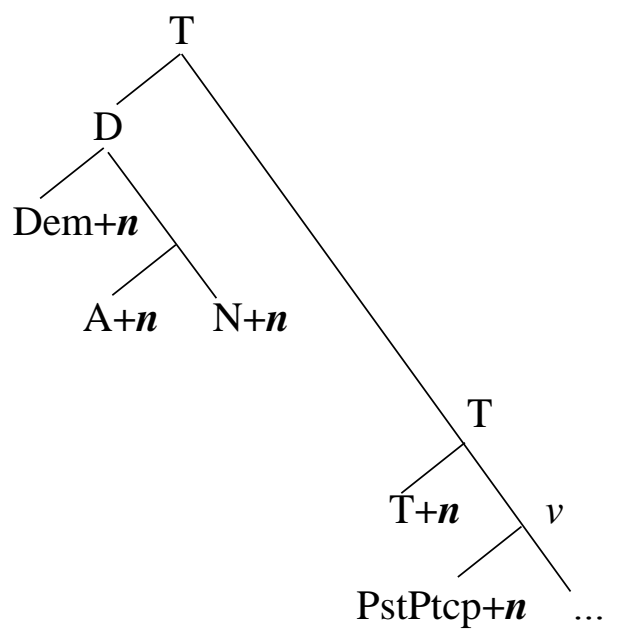

Building on this hypothesis, the next section seeks to account for the participle-like agreement of Mesolcinese finite verbs, which undergo gender and object-clitic agreement. The gist of the next section is that Mesolcinese finite verbs are subject to morpho-phonological agreement whenever they are in the c-command domain of feminine plural object and/or subject clitics.

\section{Mesolcinese: gender and object agreement on $\mathrm{T}$}

Verbal gender agreement is very rare in Romance; it is attested in few dialects scattered along the Alps and in central Italy (D’Alessandro 2016, 2017). In Mesolcinese, verbal gender agreement arguably emerged when the formative $-n$ marking $3^{\text {rd }}$ person plural agreement was lost, a phenomenon that is widespread in the nearby Lombard varieties spoken in the basin of the river Ticino (to which the Mesolcina valley belongs, see the map in Fig. 1). In the dialects of Ticino, $3^{\text {rd }}$ person singular and plural verbal forms became syncretic because the ending $-n$, marking $3^{\text {rd }}$ person plural agreement, was lost (Salvioni 1902), e.g. kanta- $n>$ kanta 'they sing' $=$ 'he/she sings'. 
Mesolcinese varieties were subject to the same innovation, which targeted the (masculine) person ending $-n$, but spared the homophonous $+n$ marking morphophonological concord/agreement ( $\$ 5)$. Once the full-fledged Person ending $-n$ was lost, $3^{\text {rd }}$ person plural verbs became syncretic with $3^{\text {rd }}$ person singular verbs in the masculine, whereas in the feminine the marker $+n$ kept occurring, yielding the present-day pattern of verbal gender agreement:

(29) proto-Mes./Breg. Mes.
a. kanta-n
$>\quad k a n t a(*-n)$ 'they.M sing'
b. kanta-n
> $k a n t a+n$ 'they.F sing'

The change in (29) is not documented in the present indicative, but a similar evolution can be observed in the future, where the emergence of verbal gender agreement is more recent than in the present indicative. According to the data contained in the AIS (which were collected almost a century ago), the future exhibited the inflectional ending $-n$ with feminine and masculine subjects, see (30), until the first half of the $20^{\text {th }}$ century. Nowadays, the formative $-n$ can no longer co-occur with masculine subjects, cf. (31)a, while it is restricted to feminine subjects in the future as well as in the present, cf. (31)b:

(30) i foràn kel k' i voràn (Mes. AIS)

they.M= do.FUT.3PL that that they.M= want.FUT.3PL

'They will do what they will want.'

(31) a. i $\quad$ fa'ra(*n) kel $\quad$ k $\quad$ i $\quad$ vo:(*ran)(Mes. 2017)

they.M= do.FUT.3PL that that they.M= want.FUT.3PL

b. la fa'ra-n kel ke la vo'ra-n

they.F= do.FUT.3-F.PL that that they.F= want.FUT.3-F.PL 
The data in (30) and (31) support the hypothesis that "proto-Mesolcinese" - like Bregagliotto - featured two homophonous endings $(-n, \wedge n)$ : the former has been lost (as in other Lombard dialects), while the latter became a morpho-phonological marker $(+n)$.

As argued in $\$ 5$, the hallmark of morphophonological agreement is the multiple occurrence of plural exponence within a Spell-Out domain. In the remainder of the section, I elaborate on the hypothesis that, besides nominal concord, morphophonological agreement targets past participles, predicative adjectives and floating quantifiers that are in the object clitic's ccommand domain, between square brackets in (32). According to this analysis, past participles therefore agree in the same way in which determiners, adjectives, possessives and other nominal modifiers undergo concord in the DP (cf. Manzini \& Savoia's 2019 parameter in (27)):

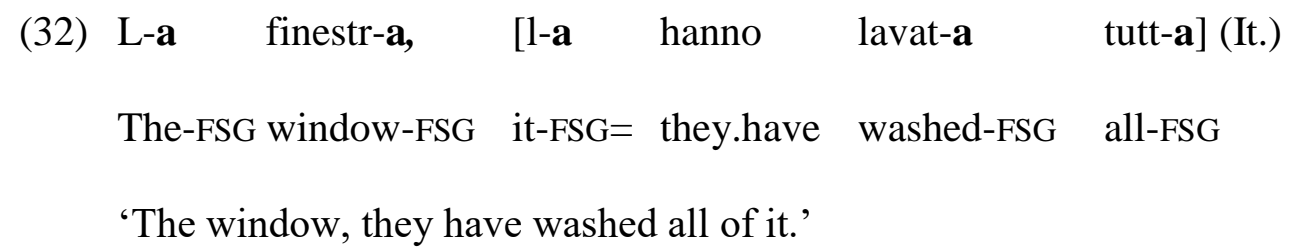

When object clitics are merged in $\mathrm{T}$, participles, predicative adjectives, and quantifiers must/can agree with the clitic - on a language-specific basis - in the same way in which nouns and nominal modifiers agree in number with $\mathrm{D}$ (or, more precisely, with the abstract PLURALISER that is merged in D, see Dobrovie Sorin 2012; Cyrino \& Espinal 2020).

The only element in (32) that is not subject to morphophonological agreement is the inflected verb, which is also the only element that agrees in Person. This complementary distribution between Person (syntactic) agreement and Gender (morphophonological) agreement has been previously noticed in the literature. For instance, Baker 2008: 85-86 points out that 
the verbal head can still agree with a nearby NP in number and gender, but should lose the ability to agree in person. Such instances of verbal agreement would be adjectivelike in this respect. (Baker 2008: 85-86; emphasis mine)

In the light of Baker's quote, I suggest that, after the original person/number ending $-n$ was lost in Mesolcinese, finite verbs at the third person began to undergo morphophonological agreement, like adjectives and participles. This pattern would be impossible in a language like Bregagliotto, which exhibits a solid mechanism of person agreement: recall that, in Bregagliotto, the PLURALISER ${ }^{\wedge} n$ is merged with person probes and is barred when $\mathrm{T}$ is valued as $1^{\text {st }} / 2^{\text {nd }}$ person because $1^{\text {st }} / 2^{\text {nd }}$ person cannot be pluralised (cf. §3). In Mesolcinese, conversely, $n$ is free to combine with verbs at any person because $n$ has become a morpho-phonological marker that can be attached to any inflected element within the Spell-Out domain of feminine plural clitics. Hence, when verbs at the $1^{\text {st }} / 2^{\text {nd }}$ person are c-commanded by a feminine plural clitic, the morphophonological marker $-n$ is attached to the verb after the $1^{\text {st }} / 2^{\text {nd }}$ person ending (the relevant example is repeated below):

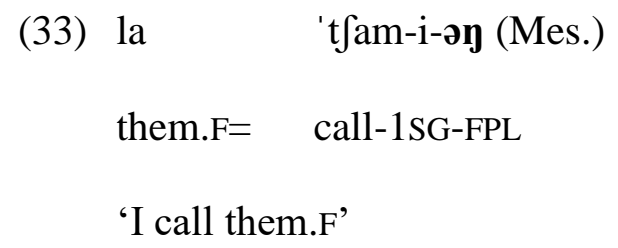

In conclusion, the hypothesis that plural $+n$ in Mesolcinese instantiates morphophonological agreement accounts for various peculiarities of Mesolcinese, noticeably why finite verbs agree in gender and with object clitics (two properties that, in the other (Italo)Romance varieties characterise past participles).

The fact that the Mesolcinese $+n$ became a morphophonological marker of number/gender agreement after the person/number element $-n$ had been lost supports the view that 
morphophonological agreement and person agreement are somehow in complementary distribution. However, the agreement pattern illustrated in (33), in which a $1^{\text {st }}$ person singular verb agrees with a feminine plural object clitic, does not corroborate Baker's idea that verbs can agree in number and gender if they lose the ability to agree in person.

\section{Conclusions}

This article examined the agreement systems of two Lombard Alpine dialects. In both varieties, feminine plural agreement/concord is marked by the formative $n$, which resulted from the reanalysis of the $3^{\text {rd }}$ person plural verbal ending.

The verbal morphology of Bregagliotto is quite regular (save for metathesis that occurs when the inverted subject clitic follows the plural formative $-n$ ). Concord within the noun phrase is marked by $-n$, which always occurs after the first element of the phrase.

Mesolcinese is more complicated as it exhibits verbal gender agreement: the formative $-n$ is attached to the inflected verb when either the subject or the object (clitic) is feminine plural. In the noun phrase, $n$ is attached to any element except the definite article.

As for Bregagliotto, I argued that metathesis was eventually reanalysed, yielding an alternation between two homophonous items: the agreement head $-n$ and the adjunct ${ }^{\wedge} n$. The latter carries feminine plural features and, unlike $-n$, it is not incorporated by the inflected verb. The formative ${ }^{\wedge} n$ is merged with person probes such as T and D.

In Mesolcinese, conversely, $+n$ does not lexicalise the adjunct pluraliser, but it is a feminine plural marker involved in morpho-phonological agreement/concord. In Mesolcinese $+n$ combines with all inflected categories within a Spell-Out domain, both at the clausal and DP level (Manzini \& Savoia 2019). The inflected verb, which, like in other Lombard dialects, shows no distinction between the $3^{\text {rd }}$ and $6^{\text {th }}$ person and can no longer undergo inversion, is 
subject to morpho-phonological, participle-like agreement: as a result, inflected verbs in Mesolcinese are combined with $+n$ when they are in the c-command domain of feminine plural subject and/or object clitics.

\section{References}

Abney, Steven Paul (1987). The English Noun-Phrase in its Sentential Aspect. Ph.D. dissenation, MIT.

AIS = Jaberg Karl \& Jud Jakob (1928-1940). Sprach- und Sachatlas Italiens und der Südschweiz, Zofingen, Ringier.

Arregi, Karlos and Andrew Nevins (2018). "Beware Occam's Syntactic Razor: Morphotactic Analysis and Spanish Mesoclisis." Linguistic Inquiry, vol. 49 no. 4, 2018, p. 625-683.

Ascoli, Graziadio Isaia (1873). Saggi ladini. Archivio glottologico italiano, 1.

Baker, Mark (2008. The Syntax of Agreement and Concord. Cambridge: Cambridge University Press.

Benveniste, Émile (1966). Problèmes de linguistique générale. Paris: Gallimard.

Bernstein, Judy (1991). DP's in French and Walloon: evidence for parametric variation in nominal head movement. Probus 3(2): 101-126.

Bianchi, Valentina (2008). 'Number agreement and event pluralization: A case study'. Phases of Interpretation, edited by Mara Frascarelli, Berlin, New York: De Gruyter, 213-236. https://doi.org/10.1515/9783110197723.4.213

Bonet, E., M.-R. Lloret \& J. Mascaró (2015). “The prenominal allomorphy syndrome”, in E. Bonet, M.-R. Lloret \& J. Mascaró (eds), Understanding Allomorphy. Perspectives from Optimality Theory. Sheffield: Equinox, 5-44. 
Bouchard, D. (2002). Adjectives, number and interfaces. Why languages vary. Amsterdam: Elsevier.

Calabrese, Andrea, Pescarini, Diego (2014). Clitic Metathesis in the Friulian Dialect of Forni di Sotto. Probus 26(2) : 275-308.

Chomsky, Noam (2001). Derivation by Phase. In M. Kenstowicz (Ed.), Ken Hale A Life in Language. Cambridge, MA: MIT Press, 1-52.

Chomsky, Noam (2004). Beyond Explanatory Adequacy. In Structures and Beyond: The Cartography of Syntactic Structures, Volume 3, ed. Adriana Belletti, 104-131. New York: Oxford University Press.

Chomsky, Noam (2020). The UCLA lectures. lingbuzz/005485

Cyrino, Sonia and Espinal, Maria Teresa (2015). Bare nominals in Brazilian Portuguese: more on the DP/NP analysis. Natural Language and Linguistics Theory 33:471-521.

Cyrino, Sonia and Espinal, Maria Teresa (2020), On the Syntax of Number in Romance. Studia Linguistica, 74: 165-203.

Delfitto, D. \& Schroten, J. 1991. Bare plurals and the Number affix in DP. Probus 3:155-185.

Dobrovie-Sorin, Carmen (2012). Number as a feature. In L. Brugè, A. Cardinaletti, G. Giusti, N. Munaro \& C. Poletto, Functional heads. Oxford: Oxford University Press, 304-324.

D’Alessandro, Roberta (2016). Floating Features in Syntax: Person, Deixis and Agreement in Italo-Romance. Talk delivered at the $46^{\text {th }}$ Linguistic Symposium on Romance Languages, University of New York at Stony Brook, March 31-April 3, 2016.

D’Alessandro, Roberta (2017). When you have too many features: Auxiliaries, agreement and clitics in Italian varieties. Glossa: A Journal of General Linguistics, 2(1), 50.

Espinal, M. Teresa. (2013). On the structure of vocatives. In Barbara Sonnenhauser and Patrizia Noel Aziz Hanna (eds), Vocative! Berlin: De Gruyter, 109-132.

Grassi, Linda (2008). Profilo linguistico del Grigioni italiano. Quaderni grigionitaliani 77: 449466. 
Guardiano, C. (2010) Demonstratives and the structure of the DP: crosslinguistic remarks. Paper presented at the Workshop on Disharmony in Nominals, Linguistics Association of Great Britain Annual Meeting, Leeds University, September 2010.

Harris James \& Morris Halle (2005). Unexpected plural inflections in Spanish: reduplication and metathesis. Linguistic Inquiry 36(2): 195-222.

Hornstein, Norbert \& Nunes, Jairo. (2008). Adjunction, Labeling, and Bare Phrase Structure. Biolinguistics. 21. 57-86.

Jaberg, Karl (1951-1952). Über einige alpinlombardische Eigentümlichkeiten der Mesolcina und der Calanca. Vox Romanica, 12: 221-245

Kayne, Richard (2010). Toward a syntactic reinterpretation of Harris \& Halle (2005). In Reineke Bok-Bennema, Brigitte Kampers-Manhe and Bart Hollebrandse (eds.), Romance Languages and Linguistic Theory 2008: Selected papers from 'Going Romance' Groningen 2008. Amsterdam: Benjamins, 145-170.

Keller, Oscar (1932). Di alcune forme verbali nella parlata di Mesocco. Bollettino dell'opera del Vocabolario della Svizzera italiana 8: 259-263.

Longobardi, Giuseppe (1994). Reference and Proper Names: A Theory of N-Movement in Syntax and Logical Form. Linguistic Inquiry 25(4): 609-665.

Longobardi, Giuseppe (2001). Formal Syntax, Diachronic Minimalism, and Etymology: The History of French Chez. Linguistic Inquiry 32(2), 275-302.

Longobardi, Giuseppe (2008). Reference to individuals, person, and the variety of mapping parameters. In Henrik Høeg Müller and Alex Klinge (eds), Essays on Nominal Determination: From morphology to discourse management. Amsteradm: Benjamins, 189211.

Loporcaro, Michele (2006). Crossing form and function: first and second person plural imperatives in the dialect of Mesocco. Folia linguistica, 40(1-2): 135-154.

Lyons, John. 1968. Introduction to theoretical linguistics, Cambridge University Press. 
Manzini, Maria Rita \& Leonardo Savoia (2019). N morphology and its interpretation: Romance feminine/plural - a. In Cruschina, S., Ledgeway, A. Remberger, E.M., Italian Dialectology at the Interfaces, Amsterdam: Benjamins, 257-293.

Manzini, Maria Rita et al. (in press). Microvariation and macrocategories: Differential Plural Marking and Phase theory. L'Italia Dialettale.

Mathieu, E. 2009. From local blocking to cyclic agree. In Determiners: Universals and variations, eds. J. Ghomeshi, I. Paul \& M. Wiltschko. Amsterdam: John Benjamins, 123158.

Meyer-Lübke, Wilhelm (1890-1899). Grammatik der Romanischen Sprachen. Leipzig: Reisland.

Nevins, Anrew (2011). Multiple agree with clitics: person complementarity vs. omnivorous number. Natural Language and Linguist Theory 29, 939-971

Pescarini, Diego (2020). L'accordo asimmetrico nel Grigioni italiano. Convergenze morfologiche e divergenze sintattiche. L'Italia Dialettale 81: 213-244.

Picallo, Carmen (1991). Nominals and nominalizations in Catalan. Probus 3:279-316.

Rasom, Sabrina 2008. Lazy concord in the Central Ladin feminine plural DP: A case study on the interaction between morpho-syntax and semantics. Padua, University of Padua. PhD diss.

Ritter, E. 1991. Two functional categories in noun phrases. Syntax and semantics 25:37-62.

Ritter, E. 1992. Cross-linguistic evidence for number phrase. Canadian Journal of Linguistics/Revue canadienne de linguistique 37:197-218.

Rizzi, Luigi (1997). The fine structure of the left periphery. In Liliane Haegeman, Elements of Grammar. Handbook of Generative Syntax. Dordrecht : Kluwer, 281-337.

Salvioni, Carlo (1902). Del plurale femminile di prima declinazione esposto per -a ed -an in qualche varietà alpina di Lombardia. Rendiconti del Reale Istituto Lombardo di Scienze e Lettere (s. 2) 35: 905-919. Reprinted in C.S., Scritti Linguistici, ed. by M. Loporcaro et al., vol. I. Bellinzona, Edizioni dello stato del cantone Ticino, 133-147. 
Schuchardt, Hugo (1880) [Rez. von:] Ernst Windisch, Kurzgefasste Irische Grammatik mit Lesestücken. Zeitschrift für romanische Philologie 4: 124-155.

Sganzini, Silvio (1933). Di alcune forme verbali nella parlata di Mesocco. L'Italia Dialettale 9: $259-263$

Stark, E; Pomino, N (2009). Adnominal adjectives in romance. Where morphology seemingly meets semantics. In: Espinal, M T; Leonetti, M; McNally, L. Proceedings of the IV Nereus International Workshop: Definiteness and DP Structure in Romance Languages. Konstanz, Germany: Fachbereich Sprachwissenschaft der Universität Konstanz, 113-135.

Tuttle, Edward (1982). Per l'origine dei plurali in -n nel Grigioni italiano: poligenesi e parallelismi strutturali. Vox Romanica 41: 73-94.

Wiltschko, M. (2008). The syntax of non-inflectional plural marking. Natural Language and Linguistic Theory 26:639-694. 